\title{
Half-Hearted Democracy: Critical Discourse Analysis of Public Service Cases in West Sumatra
}

\section{1st Agustina*}

Dep. of Indonesian Literature, Faculty of Languages and Arts, Universitas Negeri Padang,

Padang, Indonesia

agustina@fbs.unp.ac.id

\author{
2ndMuhammad Adek \\ Dep. of Indonesian Literature, Faculty of Languages \\ and Arts, Universitas Negeri Padang, \\ Padang, Indonesia \\ marximalize@fbs.unp.ac.id
}

\begin{abstract}
The establishment of the Law on Public Services in Indonesia has opened the widest possible space to improve public participation in government. Public participation currently became an integral factor in the assessment of subsequent democratic practices. The evaluation of public participation in general can be reviewed from the reporting of mass media texts as one of the mediums to accommodate public aspirations. One form of public participation is supervision of the implementation of services and policies. The local mass media manuscript in West Sumatra was chosen as the material object of this study. By using Sawirman's BREAK combined with Foucauldian discursive approach; it was found two competing
\end{abstract}

\section{INTRODUCTION}

After the fall of the New Order, the Indonesian government tried to perform massive reforms, especially in governance [1], [2]. One important issue is bureaucratic reform through standardization of public services. Unquestionably, the decay of state institutions has been complete and corruption practices are rampant to the lowest level [3]. Until finally it was formed the Law on Public Services as the main guideline. Since it was decided, the state began to involve its citizens as an important element in public policy governance.

The Law on Public Services provides the widest possible space for citizens to play an active role in the government process, especially in public policy supervision [4], [5], [6], [7]. discourses concerning the portrait of public services in Indonesia. Primary discourse contains complaints from the general public regarding the implementation of public services by the regional government of West Sumatra which is still congested in order to create an undemocratic atmosphere. Secondary discourse contains the demands and mandate of public service reform which the central government wants to realize as an effort towards a new brand democratic state. These two contrasting discourses move in opposition and conflict with each other which detain the democratic process in Indonesia.

Keywords-Discourse Analysis, Democracy Index, West Sumatra

Citizens are invited to contribute more in creating synergic governance between the people and the government. Moreover, public perception can also be utilized as a parameter of democratic practice in the modern era [8].

Citizen participation becomes an important process to create a democratic atmosphere from a government. Portraits of public participation usually appear and are recorded in the news in the daily mass media [9]. The mass media can actually be an effective forum for receiving complaints or protests by citizens regarding public policies. Then, analysis of mass media texts has the potential to reveal how a policy is implemented and how the public reacts to the policy. 
Research using critical discourse analysis has capabilities to unravel the webs of power spread through knowledge which here is represented by texts in the mass media. Collins, for example [10], highlighted the discourse about union opposition to the closure of shipyards in Glasgow, during the 1970s. Collin uses discourse analysis to examine the text in detail to understand the background of disputes. Collins in his analysis emphasized the values embedded in speech and text [11]. Discourse analysis at this level can be used to understand changes in public policy.

Furthermore, Stenson and Watt [12] use Foucauldian discourse to study the two texts on economic regeneration of local governments produced by policy makers in the United Kingdom in the late 1990s. They argue that advocates of neo-liberal policies have succeeded in incorporating the language of socialdemocratic discourse to secure greater legitimacy with the help of the wider community. More recently, Marston [13] used a critical discourse analysis in a review of the housing policy process. By using the Fairclough approach, Marston highlighted how the 'ideological cues' worked to bring about policy change. Following study was conducted by Arapoglou [14] which is highlighted governance for the homeless in Greece. He compared sources from the primary text on policy and interviews with policy-making actors. This is intended to reveal how philanthropic and managerial discourse is used by government institutions to justify their intervention in providing services to homeless people.

In this article, the discourses will be discussed relating to the issue of public services as one of the benchmarks for implementing democracy in Indonesia. Specifically, the text of selected local mass media in West Sumatra was used as a data source that illustrates the implementation of democracy by local governments. The discourse will be compared with public service reform discourse sourced from the Public Service Act. The comparison of the two discourses is expected to reveal the problems that arise regarding the implementation of public services.

\section{METHOD}

This research highlights public complaints as one of the benchmarks of implementing democracy in the province of West Sumatra in 2016 as the object of research. This selection was based on the low rank of the index of democracy in the province of West Sumatra on a national scale. The data in this study were sourced from texts in local mass media (Singgalang) in West Sumatra during the 2016 period. The selection of this data was adjusted to the data sources used by the Central Statistics Agency (Badan Pusat Statistik or further 'BPS') in measuring the democracy index in Indonesia.

Data analysis process referred to Sawirman's BREAK theory [15] which is including the position of discourse that is competing in the community regarding complaints about public services; scrutinize the linguistic configuration that compiles the discourse being compared; compare the types of movements between discourses that are compared. Furthermore, this article treats the term public complaint as a discourse. The researcher specifically refers to Foucauldian discourse approach which defines discourse as a practice/statement that is regulated to achieve certain goals [16]. Mills [17] also agrees that Foucauldian discourse analysis is very suitable to be applied to see how the relation of truth, power and knowledge.

\section{RESULTS AND DISCUSSION}

\section{A. Position of the discourse}

In BREAK theory, the Discourse Position feature is intended to make categorization. In this case, there are two selected sources of compared discourse. The first type is public complaints; the second is public service reform. To facilitate the classification process between the two discourses, each discourse will be separated into two: primary and secondary discourse. To be clearer, the primary discourse acts as the main discourse and the secondary comes as a comparing discourse.

The parameter that will be used as a benchmark of discourse is based on the focus and purpose of the study. Referring to the objectives 
of the research problem that wants to reveal how democratic practices are through evaluating government administration, the indicator that can be used as a reference is public complaints about its implementation at the practical level. Therefore, the discourse on public complaints was chosen as the primary discourse.

Table 1. Identification of Position of Discourse

\begin{tabular}{lll}
\hline Position of the Discourses & Primary & Secondary \\
\hline Based on the research focus & public complaints & public service reform \\
& & \\
\hline
\end{tabular}

\section{B. Configuration of the Discourse}

The meaning, message and purpose of a discourse do not immediately appear on the surface layer in a structure unit. Therefore, the decomposition of the relationship between the syntactical elements will reveal the discourse that the structure wants to express. In this study, the concept of searching for discourse was carried out on expressions found in the news script in the mass media.

The uniqueness of the language from mass media reporting should be discussed with content analysis method. Content analysis treats language as something very dynamic and tricky because the range of meanings made is very fluid and open. However, an in-depth study of content and enriched with context will guide the workings and analysis process to obtain a comprehensive explanation. This is what content analysis methods say as methods and techniques [18], [19], [20], [21], [22].

\section{1) Primary Discourse: Analysis of Form, Essence, Spirit}

a) Form Analysis

The first form of the public complaints discourse in the mass media text is a factual report. 'Factual' term refers to the nature of mass media texts that can record events that have occurred in people's daily lives. The mass media has work procedures that can strengthen the legitimacy and validity of the news reported. By including the details of the incident, the truth of the news text can be justified. Typically, public complaints discourse in the mass media text has a structure in the form of transitive sentences. This means that the structure requires the presence of Objects for the purpose from the actions brought about by the Predicate.

That pattern can be found in the following data: (1) Korban pengeroyokan dating kantor DPRD Agam-'The beating victims came to DPRD Agam office'; (2) Guru tidak tetap keluhkan honor berkurang-'Non-permanent teachers complain that salaries are reduced'; (3) 40 rumah tangga miskin dambakan listrik-'40 poor households crave for electricity'.

There is a striking repetition pattern namely the mention of the subject in detail. Subjects are displayed by adding specific information such as "beating victims", "non-permanent teachers" and "poor households." This emphasis can create certain perceptions and points of view from the readers. Another interesting scheme identified is the omission of the Object. The presence and clarity of the Object's identity in the text are not as clear as the Subject. There are two possibilities for this formation. First, the speaker attempt to neglect it from the reader so that the Object does not appear or display. Second, annulling the position of the object in a certain "predicate-object pairing" appears in the passive form and consider it not as the Object of position: (4) Warga perumahan Talang keluhkan saluran drainase'Residents of Talang housing complain about drainage channels'; (5) Warga Lolo Kasik mengeluh banyak jalan berlubang-'Residents of Lolo Kasik complain that there are many potholes'; (6) Sejumlah warga mempertanyakan keselamatan penumpang angkutan-'Some residents questioned the passenger's safety'. 
In data (4), the object identified is drainage channel. The noun phrase "drainage channel" is a passive noun (inanimate-noun) which cannot directly feel or accept the transfer of action from a predicate (verb of activity). Similar structures also appear in data (5) and (6) where the function of the object acting as a patient (undergoer) is inanimate-noun which is "pothole" and "passenger's safety". Thus, the direction of the activity transferred by the Subject does not get the right goals and objectives.

Therefore, the predicate function is very fundamental in exposing the idea of a sentence unit. The predicate that often appears in the public complaint discourse is as follows: (7) Supir keluhkan pungutan pemeliharaan jalan-'The driver complains about road maintenance fees'; (8) Orang tua siswa SD protes materi pelajaran pendidikan jasmani-'Parents of elementary school students protest physical education subject'-(9) Masyarakat melaporkan buku pelajaran SD memuat unsur vulgar.-The community reported elementary school textbooks containing vulgar content'.

The predicate identified in data (7) is "mengeluhkan" (complaint) which is transformed from the word "keluhkan". This predicate function is categorized as an action verb. In this case, the relationship between subject and object should be equal so that the action/message can be transferred. However, as explained in the previous analysis, the status between subject and object is not equal because the object is a class of inactive nouns (inanimate-noun). This inequality is also repeated in data (8) and (9) where the Subject is orang tua (parents) and masyarakat (community) paired with 'materi (material)' and 'buku ajar (textbook)' Objects (which is inanimated noun) which do not complement each other.

The second form of the public complaints discourse found in the mass media text is opinion coverage. Opinion piece here is in the sense that the mass media has the capacity to report and publicize opinions that are developing in the community. This opinion can be sourced from the voice of a group of people, survey, interviews, study results, or expert/scholar opinions.
Although opinions tend to contain subjective views, however it still must not ignore the principles of universal truth and propriety. Public complaints discourse that appears in the mass media text has a diverse structure.

The first pattern identified is the unclear identity of the subject. In the public complaints discourse in the form of factual reports, subjects are presented with specific characteristics so that they are easily identified. However, in opinion news, such specialties are no longer visible and are replaced by a common identity (modest) such as "people" (data 10 and 13), "drivers" (11), "Payakumbuh elections" (12); (10) Masyarakat keluhkan Pilkada kurang semarak-'People complained about lack of excitement of local election'; (11) Kosongnya BBM mengundang penilaian negative dari pengemudi-(11.1) Pengemudi menilai negative kosongnya BBM-`The driver judged negatively about fuel's out of stock'; (12) Pilkada Payakumbuh lesu darah'Payakumbuh elections was unenthusiastic'; (13) Masyarakat kecewa terpangkasnya anggaran Pokir'People are disappointed that the Pokir budget has been cut'.

Besides, the identity of the intended Object also does not contain coherence. Both factual reports and opinion news together use formulas that are not much different. Moreover, the four propositions above contain pairs of Objects and Subjects that are not synchronous. In data (10), the Object with the noun-static word class 'Pilkada' can not accept the action transferred predicate 'complaint' from the subject function to the nounactive word class 'people.' The same thing is repeated in data (11) and (13), the subject-object pair is also not compatible. Data (12) does not present an object at all because the grammatical structure is only filled by the S+P function.

\section{b) Essence Analysis}

The clearness or absence of the identity of the subject in the above structures indicate the urgency of the report. In factual news, the Subjects make an issue of the things that are very important and urgent in their lives. This can be seen from the contents of the lexicon of Object functions such as 'beating victims', 'non- 
permanent teachers' and 'poor households'. The addition of explanatory features attached to nouns to the function of the subject also gives the reader knowledge that the Subjects come from a weaker party (beating), lesser power (nonpermanent; poor) and want justice for their lack of rights.

In opinion news, the function of the subject is vague without followed adjective such as in the data: 'people', 'driver, 'local elections.' This is also closely related to the urgency of the things discussed by the preposition which is not too substantial and urgent, for example 'atmosphere of local election', 'fuel availability', 'budget repeal.' The incoherency in this case refers to the inability of the Object's function to accept the action transferred by the Subject's function. In other words, the Object presented by the structure is incorrect. In the data "beating victims came to the Regional People's Representative AssemblyDewan Perwakilan Rakyat Daerah (DPRD) Agam office", it appears that the intended object by the subject function is not the accurate one. The subject of 'beating victims' is a criminal case that should come to the police station. However, the function of the Object presented in this construction is the DPRD which cannot receive that action.

The disagreement between subject-objects can indicate several issues. The first is the lack of knowledge from the injured party regarding the bureaucratic process in governance. It is undeniable fact that many Indonesian people are still blind and allergic to the bureaucratic process [23]. Many factors caused this, including the closed bureaucratic process during the New Order Era and extensive nepotism [24], [25]. The second premise is the majority of citizen is no longer trust the bureaucratic process. Bureaucracy in practice requires strict procedures (rule) and tiered (hierarchy) so it is often considered to be a non-solutive way to solve problems [26]. The injured party especially when it comes to an urgent interests ultimately prefers shortcuts to find the fastest way to fulfill their sense of justice. This is seen in the subject's action 'victim' on data (1).
The manifestation of the first premise can be found in data (2), (3), (4), (5) and (6). The function of the subject which is the parties impaired their rights as citizens do not know exactly how the bureaucratic process is implemented. The points at issue such as 'fees', 'electricity', 'drainage', 'roads' and 'safety' do not get clear directions and goals for processing and completion. Until finally, the injured subjects seem to lose direction and despair about their problem which is reflected in the following verbs: complaints, dreams, and questions. In the public complaints discourse in the form of opinion news, the appearance of incoherent object functions is repeated. The messages that the subject wants to channel through the predicate are floating again and do not find a solution. The verbs that fill the predicate function which is displayed through lexicons 'complaining', 'judging', 'disappointed', 'unenthusiastic' ultimately it only becomes a durative activity that does not show results (telic).

The obscurity of the diction occupying the predicate function signaled a message of doubt. These doubts stem from the two premises previously discussed: illiteracy of the community in the bureaucratic process and the disobedience of citizens (as an injured party) to the practice of democracy in Indonesia. In the example of a predicate 'complaining', 'dream of', 'disappointed', 'questioning', the subject is described as doing unproductive activities, which do not have much impact on changing circumstances. This is more likely to originate from the subject's unfamiliarity of the matter complained of rather than a bureaucratic insolence. Data (8) and (9) give a strong predicate in explaining the subject's actions, including protesting and reporting. The damaged subjects can change the situation and fulfill their sense of justice through this activity. However, this activity becomes counter-productive because the problem discussed is not an urgent need such as a subject matter. In this primary discourse, the function of predictive aspects which should explain something that is owned, experienced, felt, defined or completed correctly by the subject does not apply as it should. 


\section{c) Spirit Analysis}

The detail of the Subject's identity and reference as the party discussed in the public complaints discourse shows the spirit of exposure to the injured party. This explicit exposure will ignite conversation and give birth to knowledge in the midst of society. Through this discourse, the mass media suggests that there are still many people from a certain class/identity who are still having difficulty getting attention and service from the government as the organizer of democracy. Fulfillments of basic rights such as a decent and peaceful life as citizens are still a major problem.

On the other hand, the asynchronous identity of the Object as the target/objective activity of the Subject function shows the spirit of public service deadlock. The bureaucratic reform that was echoed after the fall of New Order reign did not work anymore, which is marked by the many problems that are echoed by the Subject. All problems complained of by the Subject in general (in these case citizens) should be the responsibility of the state. Issues related to the lives of many people and decent lives are regulated completely by the state and guaranteed by the Constitution. However, this great narrative is not really understood until it is widely practiced by every citizen.

The obscurity of diction which fills the predicate function reflects the spirit of inequality between citizens and the government. In more detail, citizens do not feel the presence of the state as a solution to their problems. This can be seen from the types of verbs that represent the activities/situations of citizens. Based on the analysis of the appearance of identity, the predicate that most often occurs is mengeluh (complaints) (data (2), (4), (5), (7), (10)). Complaining here shows the ignorance of citizens in finding a way out or lose hope to get their rights back. This situation reinforces the two premises previously mentioned: unawareness of citizen in the bureaucratic process or distrust of netizen in the democratic process.

2) Secondary Discourse: Analysis of Form, Essence, Spirit
Discourse which is decided as a comparison of primary discourse is public service reforms echoed by the Republic of Indonesia government. The formal object comes from document of [27] Law number 25 year 2009 about Public Services.

a) Form Analysis

In general, the linguistic form of this secondary discourse is a directive speech act. The term 'directive' here means that a party has more power than other party so that the superior party is able to direct the inferior party in acting and making decisions. In this case, Law number 25 Year 2009 has the role as director and the state apparatus as the directed party. Furthermore, the form of directive speech acts makes the state apparatus have a reason (basic/legal provisions) to act (to perform public service). In connection with these relations, the state in carrying out public services must be in accordance with the guidelines stipulated in [27] Law number 25 Year 2009. Some directive speech data listed in the selected Public Service Law are as follows:

(1) Negara berkewajiban melayani setiap warga negara ... ('The state is obliged to serve every citizen ...')

(2) ... pelayananpublikmerupakankegiatan yang harusdilakukan ... ( '... public service providers is an activity that must be implemented ...')

(3) Penyelenggara dan pihak lain wajib mencantumkan alarnat... ('The provider and other parties must include ...)

(4) Penyelenggara berkewajiban membantu masya rakat ... ('The provider is obliged to assist the community ...')

(5) Penyelenggara berkewajiban memberikan pelayanan ... ('The organizer is obliged to provide services ...').

From the data above, it is found that two entries occupy a predicate that reflects directive speech acts, which are 'berkewajiban' to oblige and 'wajib' must to. Judging from the semantic aspect, both contain components of meaning that are not much different: [+directing others+coercing+in power]. The use of the two does not differ greatly and can be exchanged with each other. 


\section{b) Essence Analysis}

Based on the analysis of the form, the discourse of public service reform in Indonesia is plenty of directive speech acts. The directive speech acts theoretically have several levels of force, from the weakest to the strongest. From data related to public service discourse, it can be measured from the predicate chosen as an illocutionary point. Because through predicate, it is explained what actions are directed by the director to be directed. From the identified predicates above, several verbs were found with similar variations such as 'berkewajiban', 'wajib' (to oblige), 'harus' (must to). These verbs are in an identical field of meaning: the steering party forces the directed party to do something. The directed party has no other choice but to follow the direction of the directing party. This is caused by the power relations that tie up both parties.

In other words, the Constitution as the highest legal foundation in the country of Indonesia has sought to instruct the state apparatus in various regions to carry out public services as well as possible. This intention is reflected in the choice of verbs with the strongest level of force compared to other verb choices for example: suggesting, asking for, etc. This statement also means that there is no alternative meaning in this process other than providing the best service for citizens.

c) Spirit Analysis
The spirit contained in the discourse of public service reform is the active role of the state in the process of fulfilling the rights of citizens through public services. As stated in the analysis of primary discourse, that most citizens in Indonesia do not aware even unknowing about bureaucratic process in public service. To bridge this problem, the process of the distribution of public services is to spread down. This is reflected in the pattern and structure of the same sentence and repeated which implies a clear pattern of relations between the state and citizens.

The choice of verb with the strongest illocutionary point level also creates the intonation of necessity. The necessity here means that the state apparatus has a responsibility in carrying out services to provide education to citizens. The low awareness of bureaucrats in carrying out public services makes the government must take a forceful approach. This also means that the state apparatus must open as wide as possible in accommodating complaints, aspirations and voices of the people as an act of direction for their work.

\section{Type of Movement of the Discourse}

Based on the analysis results on discourse configuration features, then the types of movements of the two discourses are compared can be illustrated through the following table:

Table 2. Comparison of Discourse Movement

\begin{tabular}{lll}
\hline & Primary Discourse & Secondary Discourse \\
\hline Essence & $\begin{array}{l}\text { Unawareness and mistrust of citizen } \\
\text { towards public service }\end{array}$ & $\begin{array}{l}\text { The state's obligation in } \\
\text { performing public services }\end{array}$ \\
\hline Spirit & Public service deadlock & $\begin{array}{l}\text { More active role from central } \\
\text { government }\end{array}$ \\
\hline Result & Undemocratic atmosphere & Democratic atmosphere \\
\hline Type of movements & Divergent (DI) & Divergent (DI) \\
\hline
\end{tabular}

Based on table 2, only one type of discourse movement is identified. Primary and secondary discourse has unrelated movements, or categorized as divergent-divergent (DI-DI) type. The characteristics of the movements of these two discourses are uncooperative and conflicting. That is, the essence and enthusiasm contained in each form of discourse has incompatible goals and do not support each other.

\section{CONCLUSIONS}

According to the analysis of the discursive position, the main discourse is occupied by public complaints; secondary discourse is Public Service 
Reform. This classification is based on the focus of research: for a portrait of democratic practices in province of West Sumatra. Moreover, the main discourse also discusses the voices of citizens about the implementation of public services at the regional level. Both discourses configuration display several important points. Primary discourse contains the structure of expressions that emphasize the identity of the subject's function, blurring its predicate and hiding the presence of the object, which means neglecting public services that are motivated by public service deadlock. Secondary discourse is in the form of directive speech acts with the strongest level bringing the essence of duty to the enforcement of public services in the spirit of an active role of Indonesian government. For this type of movement, primary and secondary discourse has a contrasting type of movement, namely DI-DI. The essence and spirit contained in the two forms of discourse are so different and contradictory.

\section{REFERENCES}

[1] Carothers, T. (2009). Stepping Back from Democratic Pessimism. Washington, DC: Carnegie Endowment for International Peace.

[2] Diamond, L. (2010). Indonesia's Place in Global Democracy, in Problems of Democratisation in Indonesia: Elections, Institutions and Society, ed. Edward Aspinall and Marcus Mietzner, 21-49. Singapore: Institute of Southeast Asian Studies.

[3] Davidson, J. S. (2009). Dilemmas of Democratic Consolidation in Indone sia. The Pacific Review, vol. 22, no. 3, pp. 293-310.

[4] Manor, J.(1999). The Political Economy of Democratic Decentralization. Washington: World Bank, Direction in Development.

[5] Blair, H. (2002). Participation and Accountability at the Periphery: Democratic Local Governance in Six Countries. World Development, 28(1).

[6] Pimbert, M. and T. Wakeford. (2001). Overview - Deliberative Democracy and
Analysis of the basic features of the two discourse compared implies at least three important points. First there is the inequality of vision between the central government and the regions, especially in the aspect of public services. Second, citizens' knowledge and awareness in the process of public services, especially in terms of fulfilling the basic rights of citizens is still fairly low. Third, public service deadlock highly contributed to lowering the democratic index number.

\section{ACKNOWLEDGMENTS}

This research was funded by Ministry of Research, Technology and Higher Education through DIPA-042.06.1.401516/2019. Thanks to Minister and Director General of DRPM through the Chancellor and Chairperson of LP2M of UniversitasNegeri Padang.

Citizen Empowerment. PLA Notes 40: Deliberative Democracy and Citizen Participation. London: International Institute for Environment and Development.

[7] Fung, A, and E. O. Wright, (eds).(2003). Deepening Democracy. Institutional Innovations inEmpowered Participatory Gover nance. London and New York: Verso Press.

[8] Mani, A., and Mukand, S. (2007). Democracy, visibility and public good provision. Journal of Development Economics, vol. 83, no. 2, pp. 506-529.

[9] Curran, J. (2011). Media and Democracy. London: Routledge.

[10] Collins, C.(2000). Developing the linguistic turn in urban studies: language, context and political economy. Urban Studies, 37(11), pp. 2027-2043.

[11] Collins, C.(1999). Applying Bakhtin in urban studies: the failure of community participation in the Ferguslie Park Partnership, Urban Studies, 36(1), pp. 73-90. 
[12] Stenson, K., and P. Watt.(1999). Governmentality and the 'Social'.Urban Studies, 36(1), pp. 189-201.

[13] Marston, G. (2002). Critical discourse analysis and policy-orientated housing research. Housing, Theory and Society, 19(2), pp. 82-91.

[14] Arapoglou V. P.(2004) The Governance of Homelessness in the European South: Spatial and Institutional Contexts of Philan thropy in Athens, Urban Studies, 41(3), pp. 621-640.

[15] Sawirman. (2014). e135 Reader: Media Meliput Teror. Pusat Studi Ketahanan Nasional dan Universitas Andalas.

[16] Foucault, M. (1972). The Archaeology of Knowledge (Translated by A. M. Sheridan-Smith). NY: Pantheon Books.

[17] Mills, S.(2003). Discourses of Difference: An Analysis of Women's Travel Writing and Colonialism. London: Routledge.

[18] Berelson, B.(1952). Content Analysis in Communication Research. IL: Free Press.

[19] de Sola Pool, I. (1959). Trends in Content Analysis. Urbana: University of Illinois Press.

[20] Krippendorff, K. (1980). Content Analysis: An Introduction to Its Methodology (4th ed.). Newbury Park, CA: Sage.
[21] McLaughlin, F. E., and L. A. Marascuilo. (1990). Advanced Nursing and Health Care Quantification Approaches. Philadelphia: W. B. Saunders.

[22] Weber, R. P. (1985). Basic Content Analysis. Newbury Park, CA: Sage.

[23] Brown, R. A. (2006). Indonesian corporations, cronyism, and corruption. Modern Asian Studies, vol. 40, no. 4, pp. 953-992, 2006.

[24] Robison, R. (1986). Indonesia: The Rise of Capital. Sydney: Allen and Unwin.

[25] MacIntyre, A. (2000). Funny Money: Fiscal Policy, Rent Seeking and Economic Performance, in Mushtaq H. Khan and Jomo K. S. (eds), Rents, Rent Seeking and Economic Development: Theory and Evidence. Cambridge University Press, pp. 248-73.

[26] Gaus, N., Sultan, S., and Basri, M. (2017). State bureaucracy in Indonesia and its reforms: an overview. International Journal of Public Administration, 40(8),pp. 658-669.

[27] Indonesia. Ministry of Administrative Reform of the Republic of Indonesia. Law number 25 year 2009 about Public Services. 18 July 2009. Jakarta: Ministry of Adminis trative Reform of the Republic of Indonesia. Retrieved from https://peraturan.bpk.go.id/ Home/Details/38748/uu-no-25-tahun-2009 